\title{
ПЕРІОДІЗАЦІЯ РОЗВИТКУ ВИХОВАННЯ УЧНІВСЬКОЇ МОЯОДІ В ЗАКААДАХ ПРОФЕСІЙНО-ТЕХНІЧНОЇ ОСВІТИ УКРАЇНИ (1958-1991 РР.)
}

У статті на основі аналізу джерельної бази зроблена спроба облрунтувати періодизацію розвитку виховання учнівської молоді в закладах професійно-технічної освіти украйни в 1958-1991 роках.

Акцентовано, щзо при обьрунтуванні періодизацій певних педагогічних процеесів науковці зазвичай спираються на закономірності социіально-економічного й політичного розвитку суспільства, а також на історичні особливості розвитку народної освіти і педагогічної думки в циілому та виховання молодого покоління зокрема.

Проаналізовано наукові працุі С. Батишева, О. Веселової, Н. Глазунової, В. Кульчицъького, Н. Нічкало, О. Сухомлинської, в яких розглядаються періодизації розвитку різних історикопедагогічних процесів, а саме: радянської педагогіки, професійно-технічної освіти в СРСР, систели професійно-технічної освіти, виховання учнівської молоді в закладах професійнотехнічної освіти, патріотичного виховання в школах України.

На извому підьрунті відокремлено три періоди розвитку виховання учнівської молоді в закладах професійно-технічної освіти України досліджуваної доби, а саме: 1) 1958-1971 роки орієнтація на суспільне виховання учнівської молоді та формування комуністичної моралі; 2) 1972-1984 роки - посилення впливу Комуністичної партії та ідеологічного виховання, становлення "патерналізму»; 3) 1985-1991 рр. - початок демократичної перебудови виховного проиесу.

Виявлено, щзо цุі періоди відображатоть розвиток виховання учнівської молоді в закладах професійно-технічної освіти України, зумовлені впливами державної політики, розвитком педагогічної уумки та змінами соціально-економічних умов у ті часи.

Підсумовано, щзо будь-яка періодизація розвитку виховання учнівської молоді в закладах професійно-технічної освіти Украӥни не висвітлюе в повній мірі всіх умовностей, тим самим дає можливість для подальшого наукового пошуку.

Ключові слова: виховання, учнівська молодь, заклади професійно-технічної освіти, періодизація, педагогічна думка.

Постановка проблеми. На всіх етапах розвитку суспільства проблема виховання нової робочої зміни стоїть дуже гостро, особливо нині в контексті інтеграції нашої держави в європейський простір. У зв'язку з цим підвищуються вимоги й до виховання учнівської молоді в закладах професійно-технічної освіти України. Саме тому актуальним є вивчення вітчизняного історико-педагогічного досвіду в цій царині, зокрема здобутого в 1958-1991 роках, коли вихованню молоді приділялася неабияка увага.

Аналіз досліджень. Різні аспекти виховання учнівської молоді знайшли своє відображення в працях С. Батишева, О. Веселової, Н. Глазунової, В. Кульчицького, Н. Нічкало, О. Сухомлинської, які, зокрема, розглядали періодизації розвитку різних історико-педагогічних процесів, а саме: радянської педагогіки, професійно-технічної освіти в СРСР, системи професійно-технічної освіти, виховання учнівської мододі в закладах професійно-технічної освіти, патріотичного виховання в школах України.

Мета статті: обгрунтувати періодизацію розвитку виховання учнівської молоді в закладах професійно-технічної освіти України досліджуваного періоду.

*C Пислар A. Б.

us 
Викдад основного матеріалу. 3 метою виділення періодів розвитку досліджуваного явища розглянемо дослідження вітчизняних учених, дотичні до нашої проблематики.

Так, цінним доробком до нашої проблематики є праця О. Сухомлинської «Радянська педагогіка як ідеологія: спроба історичної реконструкції» (2014р.), де запропоновано таку періодизацію розвитку радянської педагогіки: науки;

-1917-1923 роки - анархо-утопічна ідеологія розвитку радянської педагогічної

- 1924-1928 роки - освітне експериментування в СРСР як педагогічна «робінзонада»;

- 1930- очаток 1950 років - сталінська педагогіка: ізоляціонізм і тотальна ідеологія;

- 1953-1964 роки - часткова демократизація радянської педагогіки в умовах «відлиги»;

- 1965-1970 роки - контрреформаційні процеси в освіті й педагогіці;

- початок 1970 років - 1985 рік - формування застійних явищ у педагогічній науці як «підточування моноліту»;

- 1985-1991 роки - всезагальна критика офіційної радянської педагогіки; розвиток демократичних, критичних педагогічних ідей [6, с. 6].

С. Батишев у своїй книзі «Нариси історії професійно-технічної освіти в СРСР» (1981 р.) на підгрунті спільних закономірностей соціально-економічного й політичного розвитку суспільства, а також, беручи до уваги історичні особливості розвитку народної освіти і педагогічної думки в цілому, виділив три основних періоди в історії професійнотехнічної освіти в СРСР [5].

Перший період (1917-1940рр.) - становлення і зміцнення радянської системи профтехосвіти і професійної педагогіки в умовах переходу від капіталізму до соціалізму, зміцнення соціалістичного суспільства.

Етапи першого періоду:

1) 1917-1920 роки - ліквідація капіталістичної системи учнівства і докорінна перебудова старої ремісницької школи, пошук нових, соціалістичних форм підготовки кваліфікованої робочої сили, централізація керівництва профтехосвітою, початок перетворення підготовки робітників відповідно принципів «нової педагогіки і соціалізму»;

2) 1921-1933 роки - формування державної системи профтехосвіти, становлення радянської професійно-технічної школи та перетворення школи ФЗУ в основну форму підготовки кваліфікованої робочої сили;

3) 1933-1940 роки - розвиток професійно-технічної школи як школи з виразною професійною спрямованістю, масовий і широкий розвиток різних форм технічного навчання на виробництві.

Другий період (1940-1958 рр.) - створення і розвиток державних трудових резервів як єдиної централізованої системи підготовки і розподілу кваліфікованих робітників 3 числа молоді.

Етапи другого періоду:

1) 1940-1945 роки - поява шкіл і училищ трудових резервів у довоєнні роки і їх розвиток у роки Великої Вітчизняної війни;

2) 1945-1958 роки - подальший розвиток системи державних трудових резервів у роки відновлення народного господарства і подадьшого зміцнення соціалізму.

Третій період (1959-1980 рр.) - перебудова і вдосконалення системи профтехосвіти у відповідності до вимог розвинутого соціалістичного суспільства та науково-технічної революції, підвищення ролі навчальних закладів профтехосвіти у підготовці висококваліфікованих робітників і здійсненні загальної середньої освіти.

Етапи третього періоду: 
1) 1959-1965 роки - перебудова системи трудових резервів і створення замість багатьох різнотипних навчальних закладів єдиного типу профтехшкіл - міських і сільських професійно-технічних училищ, переведення їх на базу школи-восьмирічки;

2) 1966-1980 роки - реалізація довготривалої програми підготовки кваліфікованих робітників на основі рішень XXIII (1969р.), XXIV (1972 р.), XXV (1977р.) з'їздів партії та постанов ЦК КПРС і Ради Міністрів СРСР про розвиток профтехосвіти $(1969,1972$, 1975, 1977, 1979 рр.).

Обгрунтовуючи кожен із вищеназваних періодів, поміж іншого, С. Батишев торкається також проблем виховання учнівської молоді в закладах професійно-технічної освіти. Це стосується й наукового пошуку Н. Ничкало щодо виховання робочої зміни.

У праці «Виховання робочої зміни» (1982 р.) вчена виділяе два важдивих періоди, що, на ії думку, вПлинули на виховання учнівської молоді в закладах професійнотехнічної освіти, а саме:

1) 1971-1975 роки - робота щодо покращення комуністичного виховання та комуністичної моралі, здійснювана в системі закладів професійно-технічної освіти громадськими i партійними організаціями (комсомол, Комуністична партія, профспілки);

2) 1978-1985 роки - забезпечення наступності в проведені виховної роботи громадськими організаціями в системі «школа - профтехучилище - підприємство ВH3» [4, с. 52-53].

О. Веселова у своїй книзі «Молода зміна робочого класу» (1983 р.) у процесі виховання учнівської молоді в закладах професійно-технічної освіти виділяє такі періоди:

1) 1959-1965 роки - зародження та розвиток наставництва як важливої форми виховання молоді;

2) 1966-1970 роки - посилення комуністичного виховання, зокрема поліпшення ідеологічного виховання $[1$, с. 52,76$]$.

Н. Глазунова у роботі «Підготовка робочої зміни (розвиток системи професійнотехнічної освіти 1959-1987 рр.)» (1987р.) виділяе такі періоди розвитку системи професійно-технічної освіти:

1) 1959-1965 роки - перебудова і вдосконалення системи підготовки кваліфікованих робітників з учнівської мододі; молоді;

2) 1966-1972 роки - зростання ролі громадських організацій у виховані учнівської

3) 1973-1983 роки - вдосконалення комуністичного виховання, формування комуністичної моралі [2, с. 26, 65-66, 76-79].

Як бачимо, хоча вчена виділяе періоди розвитку системи професійно-технічної освіти, однак усі вони безпосередньо пов'язані з вихованням учнівської мододі.

Ця проблема знайшла відображення й у наукових пошуках В. Кульчицького, який розробив періодизацію розвитку патріотичного виховання в школах України в 1945-2019 рр. На основі історико-політичних і соціально-педагогічних особливостей розвитку державних утворень на українських землях дослідник визначив «два взаємопротилежні історичні періоди патріотичного виховання, межею між якими стало утворення незалежної української держави в 1991 р.» [3, с. 3]. Для нашого дослідження значний інтерес становлять перші два періоди: ідеологічно-організаційний (19451964 рр.) та суспільно-пропагандистський (1965-1991рр.).

У 1945-1964 роках, на думку В. Кульчицького, відбувалося «становлення наукової теорії патріотичного виховання в умовах партійно-державного управління виховним процесом, нівелювання національних й особистісних особливостей, централізована уніфікація змісту навчальних програм, реалізація практики патріотичного виховання відповідно до радянської інтерпретації марксистсько-ленінської метододогії та концепції комуністичного виховання» [3, с. 3].

Науковець розділяє цей період на два субперіоди: 
1) 1945-1953 роки - час, коли відбувалося «нівелювання загальнолюдських та морально-патріотичних цінностей, їхне підпорядкування ідеї формування особистості відповідно до потреб тоталітарного режиму»;

2) 1954-1964 роки - «становлення елементів демократизації виховного процесу; розвиток патріотичних переконань згідно з комуністичною ідеологією; упровадження елементів авторитаризму в педагогічну практику» [3, с. 3-4].

У 1965-1991 роках домінували ідеї інтернаціоналізму та соціалістичного патріотизму. І цей період розділений ученим на два субперіоди:

1) 1965-1983 роки - спостерігалися «тенденції до уніфікації суспільного життя, виховання відданості ідеям Комуністичної партії і радянської влади; нівелювання особистості; посилення педагогічного морально-патріотичного впливу на учнів»;

2) 1984-1991 роки - «ухвалення документа «Основні напрями реформи загальноосвітньої та професійної школи» (1984р.), який мав суперечдивий характер, засвідчив непослідовність освітньої політики та кризовий стан радянської освіти й науки, їхнє підпорядкування ідеологічним інтересам» [3, с. 4].

Ретельний аналіз вищезгаданих та інших наукових праць, дотичних до досліджуваної проблематики, дозволяе виділити в розвитку виховання учнівської молоді в закладах професійно-технічної освіти України в 1958-1991 роках такі періоди:

1-й (1958-1971 рр.) - орієнтація на суспільне виховання учнівської молоді та формування комуністичної моралі;

2-й (1972-1984рр.) - посилення впливу Комуністичної партії та ідеологічного виховання, становлення «патерналізму»;

3-й (1985-1991 рр.) - початок демократичної перебудови виховного процесу.

Більш детальне вивчення цих періодів розвитку виховання учнівської молоді в закладах професійно-технічної освіти України досліджуваної доби може бути здійснене у подадьших наукових пошуках.

\section{Список використаних джерел:}

1. Веселова А. М. Молодая смена рабочего класса: Подготовка рабочих (в системе профтехобразования УССР). Киев: Наук. думка, 1983. 116 с.

2. Глазунова Н. И. Подготовка рабочей смены (Развитие системы профессиональнотехнического образования. 1959-1987 гг.). Киев: Высшая школа, 1987. 199 с.

3. Кульчицький В. Й. Теорія і практика патріотичного виховання в школах України (19452019 рр.): дис. ... д-ра пед. наук: 13.00.01 / Тернопільський національний педагогічний університет імені Володимира Гнатюка. Тернопіль, 2020. 490 с.

4. Ничкало Н. Г. Воспитание рабочей смены. Киев: Политиздат Украины, 1982. 199 с.

5. Очерки истории профессионально-технического образования в СССР / редкол.: С. Я. Батишев (гл. ред.). Москва: Педагогика, 1981. 351 с.

6. Сухомдинська О. Радянська педагогіка як ідеологія: спроба історичної реконструкції.

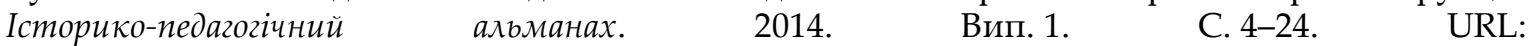
https://core.ac.uk/download/pdf/32308395.pdf

\section{References:}

1. Veselova, A. (1983). Molodaia smena rabochego klassa: Podgotovka rabochikh (v sisteme proftekhobrazovaniia USSR) [Next generation of the working class: preparing workers (in the system of vocational education in the USSR)]. Kiev: Nauk. dumka [in Russian].

2. Glazunova, N. (1987). Podgotovka rabochei smeny (Razvitie sistemy professionalno-tekhnicheskogo obrazovaniia. 1959-1987 gg.) [Preparing the next generation for the work (Development of the system of vocational education. 1959-1987)]. Kiev: Vysshaia shkola [in Russian].

3. Kulchytskyi, V. (2020). Teoriia i praktyka patriotychnoho vykhovannia v shkolakh Ukrainy (1945$2019 \mathrm{rr}$.) [Theory and practice of patriotic education at Ukrainian schools (1945-2019)]. (Extended abstract of Doctor's thesis). Ternopil Volodymyr Hnatiuk National Pedagogical University. Ternopil [in Ukrainian].

4. Nichkalo, N. (1982). Vospitaniye rabochey smeny [Upbringing the new generation for the work]. Kiev: Politizdat Ukrainy [in Russian]. 
5. Batishev, S. (Ed.). (1981). Ocherki istorii professionalno - tekhnicheskogo obrazovaniya $v$ SSSR [Studies in history of vocational education in the USSR]. Moskva: Pedagogika [in Russian].

6. Sukhomlunska, O. (2014). Radianska pedahohika yak ideolohiia: sproba istorychnoi rekonstryktsii [Soviet pedagogy as an ideology: an attempt of historical reconstruction]. Istoryko - pedahohichnyi almanakh, 1, 4-24. Retrieved from https://core.ac.uk/download/pdf/32308395.pdf [in Ukrainian].

Pyslar A. B., orcid.org/0000-0001-6843-4655

\section{CHRONOLOGY OF THE DEVELOPMENT OF THE YOUTH UPBRINGING AT INSTITUTIONS OF VOCATIONAL EDUCATION IN UKRAINE (1958-1991)}

The article describes the attempt on the basis of the literature based analysis to explain the chronology of the development of the youth upbringing at institutions of vocational education in Ukraine in 1958-1991. It is stressed that when explained the chronology of some pedagogical processes, scientists generally rely on the patterns of the socioeconomic and political development of the society, and also historical peculiarities of the development of public education and pedagogical thinking as $a$ whole and the upbringing of the young generation in particular. Scientific works of S. Batyshev, O. Veselova, N. Hlazunova, V. Kulchytskyi, N. Nichkalo, O. Sukhomlynska are analyzed in which chronologies of the development of different historical and pedagogical processes are studied namely Soviet pedagogy, vocational education in USSR, the system of vocational education, the youth upbringing at institutions of vocational education, patriotic education at schools of Ukraine. On this basis three stages of the development of the youth upbringing at institutions of vocational education in Ukraine of the researched period are highlighted namely: 1) 1958-1971 - focus on nonparental care of the youth and formation of the communist morality; 2) 1972-1984 - empowerment of the Communist Party and ideological education, formation of "paternalism"; 3) 1985-1991 - the beginning of the democratic reconstruction of the educational process. It is found out that these stages reflect the development of the youth upbringing at institutions of vocational education in Ukraine caused by the influences of the state policy, the development of pedagogical thinking and changes of socioeconomic conditions in those times. It is concluded that any chronology of the development of the youth upbringing at institutions of vocational education in Ukraine does not bring the view of all the conventions completely, in the same way it offers the opportunity for further scientific research. thinking.

Key words: upbringing, the youth, institutions of vocational education, chronology, pedagogical

Дата надходження статті: 11.01.2021 p. Реценззент: доктор педагогічних наук, доцент Яичла Т. В.

У,ДК 371.10 (438) “1960/1980" М. Демель

DOI https://doi.org/10.37915/pa.vi48.233

Сливка А. В., orcid.org/0000-0003-1865-6326

\section{ЗДОРОВ'ЯЗБЕРЕЖУВАЯЬНЕ ВИХОВАННЯ В КОНТЕКСТІ ПЕДАГОГІЧНОЇ СПАДЩИНИ МАЦЕЯ ДЕМЕЛЯ (MАСIЕЈ DEMЕL; 1923-2017)}

Статтю присвячено актуальній проблемі - вихованню дітей та молоді з метою плекання їхнього здоров'я. Зазначено, що творча спадщина польських науковців, освітян і громадсько-просвітницьких діячів у контексті иціеї проблеми заслуговуе на особливу увагу, оскільки їі переосмислення відкривае нове бачення реалізації здоров'язбережувального виховання учнів у загальноосвітніх школах України. Висвітлено зміст деяких праць лікаря, педагога,

*C Сливка А. В.

us 